University of Louisville

ThinkIR: The University of Louisville's Institutional Repository

Faculty Scholarship

$12-1993$

\title{
Symposium on basic writing, conflict and struggle, and the legacy of Mina Shaughnessy.
}

\author{
Patricia Laurence \\ CUNY City College \\ Peter Rondinone \\ CUNY La Guardia Community College \\ Barbara Gleason \\ cUNY City College \\ Thomas J. Farrell \\ University of Minnesota - Duluth \\ Paul Hunter \\ North Lake College \\ See next page for additional authors
}

Follow this and additional works at: https://ir.library.louisville.edu/faculty

Part of the English Language and Literature Commons, and the Rhetoric and Composition Commons

Original Publication Information

Laurence, Patricia, et al. "Symposium on Basic Writing, Conflict and Struggle, and the Legacy of Mina Shaughnessy." 1993. College English 55(8): 894-901.

This Article is brought to you for free and open access by ThinkIR: The University of Louisville's Institutional Repository. It has been accepted for inclusion in Faculty Scholarship by an authorized administrator of ThinkIR: The University of Louisville's Institutional Repository. For more information, please contact thinkir@louisville.edu. 


\section{Authors}

Patricia Laurence, Peter Rondinone, Barbara Gleason, Thomas J. Farrell, Paul Hunter, and Min-Zhan Lu 


\title{
SYMP O S I U M
}

\author{
on \\ BASIC WRITING, CONFLICT AND \\ STRUGGLE, AND THE LEGACY OF \\ Mina ShaughnESSY
}

\begin{abstract}
Two articles in the December 1992 College English presented bistorical perspectives on the field of Basic Writing. In "Conflict and Struggle: The Enemies or Preconditions of Basic Writing?" Min-Zhan Lu argued for the value of a pedagogy in which conflict and struggle belp Basic Writers to reposition themselves; she suggested that resistance to such a pedagogy is traceable to three pioneers in the field, Kenneth Bruffee, Thomas Farrell, and Mina Shaughnessy, and the historical context in which they worked. In "Waiting for an Aristotle," Paul Hunter analyzed the special issue of the Journal of Basic Writing published in 1980 as a memorial to Mina Shaughnessy, finding a conservative impulse both in its structure and in its reading of Shaughnessy's message. This symposium presents several commentaries on Lu's and Hunter's articles, followed by the authors' responses.

Sources for all contributions to the Symposium are combined in a common Works Cited list at the end.
\end{abstract}

PATRICIA LAURENCE, a past Director of the composition program at City College of the City University of New York, has taught at City College since the 1970s and is presently chair of the Writing in the Disciplines Program. She bas recently published The Reading of Silence: Virginia Woolf in the English Tradition and co-edited Issues in World Literature to accompany the HarperCollins World Reader (1993).

The ideology of conflict in Min-Zhan Lu's "Conflict and Struggle" subordinates our historical understanding of the field of composition and rhetoric to an ideology of political struggle. Lu outlines a pedagogy that, she states, makes "positive use of conflict," positioning Shaughnessy, Bruffee, and Farrell as gatekeepers, converters, and accommodationists who view "skills" as the cure and "conflict as the enemy" (889). Though Paul Hunter in "Waiting for an Aristotle" muffles the criticism of Shaughnessy somewhat, he suggests that the authors of

College English, Volume 55, Number 8, December 1993

Copyright (C) 1993 by the National Council of Teachers of English. All rights reserved. 
the Shaughnessy memorial essays in "Toward a Literate Democracy" (D'Eloia) conceal and "betray" in their "references to literary tradition, standard dialect, higher education, and race relations ... a distinct unwillingness . . . to criticize the history of imperialism within 'the mainstream culture" " (922). It is Lu's argument and Hunter's implication (despite his one-page "enkomion") that the teaching of reading and writing should "take place at sites of political as well as linguistic conflict" and should entail social criticism.

Having taught at City College from the beginning of Open Admissions and having been part of its educational and cultural transformation over the past twenty years (and it continues), I think that it is time that we begin to differentiate indoctrination and an education that enables student choice. In addition, it is time that professional articles such as Lu's and Hunter's describe and distinguish the various educational, cultural, and geographical sites from which different pedagogical, rhetorical, and cultural practices emerge. Fredric Jameson advises, "Always historicize," and it is the historical dimension, along with the "rich" descriptions of students and place recommended by the anthropologist Clifford Geertz, that is missing from these articles.

As I have argued in another article, “The Vanishing Site of Mina Shaughnessy's Errors and Expectations," it is time to "historicize" our interpretations of composition leaders and their pedagogical stances, framing our judgments with descriptions of their institutions and their students, as well as the educational, political, and cultural currents in which they were adrift. Now that we have a sense of the educational landscape, we should strive to capture the historical and educational moment in all of its specificity and richness. One can only smile ironically at W. E. B. DuBois, Mina Shaughnessy, Lionel Trilling, and Irving Howe set adrift by $\mathrm{Lu}$ on an educational raft-unmoored from their times, their institutions, their fields. We too, as readers of this reductive historical and educational analysis, are unmoored: uninformed about Trilling, Howe, Shaughnessy, and DuBois's identification with private, public, historically black, or graduate institutions; ignorant of their "power" in the universities in which they taught or their actual participation in the development of educational policy or practices; ignorant of their racial, ethnic, and geographical identifications. How much is missing in cultural and educational analysis that flattens the "differences" that we espouse in fashionable forums! For example, how much influence did Irving Howe have on Open Admissions, teaching graduate literature courses at the CUNY Graduate Center? DuBois emerged from an educational movement in the South in the 1920s that privileged the "talented tenth" of the black population, a position refuted by CUNY's Open Admissions policy. Similarly, one wonders, in the same vein, about Paul Hunter's historically limited view of "silence"; he recriminates the writers in Shaughnessy's memorial in 1980 and ignores the cultural silences of specialists 
today of perhaps (perhaps not) a different political stripe who continue to "appropriate" and "use" the words of Mina Shaughnessy toward their own personal, professional, and cultural ends.

The recent spate of pedagogies of conflict are offspring, I guess, of Gerald Graff's "Teach the Conflicts." Undoubtedly, there is educational value in spurring students to find problems and conceptual, linguistic, or cultural tensions in discourse: it stirs them to think and it drives what we consider "good" writing. In an attempt, however, to put "conflict" pedagogy in its "place," one might note that Graff teaches at the University of Chicago, an "elite" institution with a predominantly white student body; Drake University, Iowa, where Lu presently teaches, enrolls about 10 percent minorities, 4 percent international students (according to Peterson's Guide to Four Year Colleges, 1993); the University of Pittsburgh, where Lu taught in the past, enrolls 11 percent minority, 1 percent international students. City College, situated in Harlem, has a minority population of about 78 percent (36 percent African-American; 24 percent Hispanic; 16 percent Asian/Pacific Islanders, 1 percent Native Americans) and 9 percent international students. Given these significant differences, we nevertheless speak of Basic Writers or the "pedagogy of conflict" in blindly homogenized terms, ignoring important linguistic, cultural, and educational differences. Perhaps Graff and $\mathrm{Lu}$ assess that "conflict" strategies are needed at predominantly white, and perhaps "elite," institutions to engender a certain awareness among the students, but I would contend that the use of polarizing language in our descriptions of pedagogy does not encourage the cultural and educational understanding that we wish to encourage in a diverse society. At City College, where "difference" is structured into the institution in its 80 percent minority enrollment, there is a cultural subtext in every classroom. What surfaces are the linguistic and cultural questions and conflicts of our city and society; discussions of what Paulo Freire calls "the majority language" and the value of having many "voices" along with various cultural responses to the books we choose to read and the topics upon which we focus.

Anyone who knows the history of Open Admissions (its stormy beginnings with the student takeover of the City College campus and the burning of buildings in 1969) and the work of Mina Shaughnessy knows the stress in an institution that initiated an educational policy five years earlier than planned. Guiding institutional change, as Mina Shaughnessy did for years at City College, required a nuanced appreciation of this cultural dynamic, and in the early phases of this then controversial educational movement there was a rhetorical strategy enacted in the classroom and public forums to employ indirection and language that enhanced notions of cultural exchange and reciprocity. To have employed a vocabulary or metaphor of "conflict" or "struggle" (then or now) rather than the 
language of understanding, caring, exchange, and reciprocity would have been counterproductive, irresponsible, and explosive. This was not a "methodology" that emerged from a pedagogical community in the field of composition as it exists now in the relative calm of a second generation of composition specialists, but the strategy of an embattled faculty that understood linguistic and cultural exchange and still struggles with this powerful subtext. The balancing of sometimes global discussions of oppression and race with what Stephen North calls "the practitioner's arts" is a delicate one.

It is not just the students, however, who are "positioning" themselves on the borders, but the faculty in another "borderland" in relation to the students and to each other-in terms of ethnicity, class, and educational values. If you have read the New York Times over the past few years, we have plenty of "conflict": we have no need to "structure" it into our curriculum as a "methodology." In recent years, Leonard Jeffries and Michael Levin in their meta-dialogue about the race and intelligence of students at City College have created an educational fallout that has, at times, demoralized its students and faculty. As one of my African students said, "When two elephants fight, it is the grass that suffers." In addition, New York City has its conflicts among African-Americans, Koreans, and Jews that sometimes reverberate in the institution.

At the beginning of Open Admissions, City College faculty and administrators "negotiated" not "error" but the rage and frustrations of minority students in New York City. In 1969, these students locked "out" the faculty in order to dramatize their frustrations about getting "in." The staging of this educational drama was by students who, for the most part, were seeking an education that would enable them to join the mainstream. The resistance was not yet linguistic: the college was under cultural and physical siege. What are now metaphors for cultural conflict, "centers of resistance" or "sites of conflict," was then action. We, at City College, do not underestimate the meaning of this language or these actions. An education that enables "choice" and an appreciation of "difference" (and there are many kinds beyond language and race) is what we offer students in an already politically charged institution. "Conflict" may or may not be experienced by the student: it is not a curricular objective, and is neither expected as an educational and cultural "precondition" nor rejected (to repeat Lu's polarizing language) as the "enemy."

In the early phases of Open Admissions (and even now in more explicit and, yes, settled times), we need teachers and leaders of balance like Shaughnessy, McQuade, Bruffee, and Lyons who understand cultural change, and politics and the English language. We need those who can help us find clarity of mind and common ground in our institutions and classrooms, and nourish, as Adrienne Rich says, "the dream of a common language"-rather than language and theory that construct educational institutions as sites of political polarization. 
A native of the South Bronx, PETER RONDINONE was once an Open Admissions/Basic Writing student at the City College of New York (CUNY). He is now an English professor and Director of Journalism at LaGuardia Community College (CUNY).

I was flattered to read in Min-Zhan Lu's essay that I was one of the "new generation of minority educators" (908). However, while I accept the notion that every reading is a misreading, I do believe that Lu somewhat misunderstands my views on conflict in the Basic Writing classroom.

I'm also disconcerted that she links my views to Shelby Steele's, describing us together as a wave of "new conservatism" (909). I don't know exactly what $\mathrm{Lu}$ means by this. As a liberal, I've always thought of conservatives as those who would keep people like me out of the university. I admire Steele's work and have never associated him with my adversaries.

To the point, Lu focuses on my belief that in order to become educated there will be times when Basic Writers will have to reject or betray their family and community. She says she is "alarmed" by my "unequivocal belief that [this] choice is the a priori condition of . . . academic success" (908). To succeed in college, I had to distance myself from my uneducated family and community. So I plant the idea in the minds of Basic Writing students that sometimes their will and/or ability to enter an educated discourse community might be impeded by the people closest to them. I have hoped to open the classroom to discussions of this possibility because I've felt that this issue has long been a dirty little secret. Many compositionists have avoided facing it, yet its impact (as I have documented in my writing as both a Basic Writing student and an educator) is enormous. And I'm not the only one who has identified and experienced this destructive pressure. Think of the struggles of Richard Rodriguez. More importantly, think of all those who have ever been attacked in the schoolyard because they were carrying books! Think of the Chicano depicted in the movie Stand and Deliver who had his life threatened by his amigos because he wanted to learn math!

I'm addressing homes and communities which don't offer healthy soil for roots (to use Lu's metaphor) to take hold, such as the one I come from, which might help Lu understand why I "opted for complete deracination" (908). I have never meant to make my experience a prescription for all Basic Writing students.

Moreover, as I read Lu's essay, she suggests that my approach seeks to take conflict out of the Basic Writing classroom and somehow deprive students of Gloria Anzaldua's "mestiza consciousness" or "continual creative motion" or "tolerance for contradiction and ambivalence" leading to inner change and then social change (888). That's a mouthful. But what I take this to mean is that 
somehow students who are in the adverse conditions I describe are supposed to remain hovering between two worlds - the uneducated and the educated. This whole idea of suspension between worlds and continual motion seems naïve. It makes me suspect that Lu (and those who propose this) don't really know the street corners I'm talking about (or they've forgotten). These are places where being ambivalent, being in the middle, will get you trapped in a crossfire of lead and blown into little pieces.

Like me, many students who come from these places don't come into the classroom ambivalent. We have looked at the other side of the street, at those who use the drugs, guns, and violence, at our own homes with welfare and economic despair; and by virtue of having decided to come to college, to carry books, we have made a choice (a choice that could get our hearts cut out). We have decided to change our social allegiances. We don't need someone to tell us that we made the wrong choice, because the other choice doesn't promise much of a future. My students from the South Bronx, from Harlem, from Bushwhick, from Hollis, from Bensonhurst, from Howard Beach, and from other boods in the city tell me unequivocally: "I don't want to end up like them."

And what's so wrong? Neither these students nor I romanticize our roots. What I found, for example, was that my working poor/welfare environment didn't have many values worth clinging to. While my mother was a Russian immigrant, my Italian-American father dominated my household. His family (a family of fourteen) set the tone for my ethnic attitude. His epistemology dominated. And it was racist. When black marchers in Bensonhurst were surrounded by jeering Italian-Americans holding up watermelons, I was not surprised. When one of my brothers married an African-American woman, the Italian relatives from Jersey City whispered at the cocktail hour: brillo beads, eggplants, pineapples. It was vile and disgusting. And so when I married a Cuban/Jewish woman, I was not swearing allegiance to this group. To them, she was a two-time loser-Jewish and Hispanic.

These values not worth clinging to are not restricted to racism. There is this idea in the Italian-American community which comes particularly from Southern Italy and Sicily that children should not be smarter than their parents. So when I was in college, my father would say stuff like "So, you think you're smarter than me because you read that crap in books." At family gatherings my relatives would sneer and call me "the brain"; this wasn't a term of endearment. And so it is also no surprise (to me) that, according to the CUNY Italian American Foundation, the students with the third highest high school dropout rate in New York City are the Italian-Americans. There is a strong anti-intellectualism in this community.

Besides, for me, these aberrant values have not been limited to my ethnic background. There is the culture and the cult of the street which prizes the 
tough-talking, gun-toting idiot regardless of race, creed, or color. When I hung out on the Bronx streets, my gang was multiracial/ethnic; and when the boyz saw me in college with books they'd ride by in stolen cars and call me a "pussy." Now I should be ambivalent about this community? My students should be ambivalent?

My father worked two jobs most of his life (when we weren't on welfare). And I remember wearing shoes with holes in them and having to go to school with cold feet. I remember waiting for a welfare official to come to my house on Christmas with a box of toys. I remember going to the local U.S. armory for free blocks of cheese. But after college, I would earn more money in one hour than my father earned all week at his two crummy jobs; for then I was writing articles for OMNI magazine and getting paid one dollar a word! Now I know my four-year-old daughter Micole will never have cold feet and stale cheese to eat. And I'm supposed to be ambivalent? Italy was a place of pain my grandfather fled; my family was always eager to tell me that I was an American, even though they didn't know what the hell that meant. The best philosophy for these people, despite anti-intellectualism, became "think for yourself and try new things." So the students in Basic Writing, the displaced of the world, the poor, and the new immigrants are ready for a switch of allegiances. Plenty don't see a contradiction. They came here for a reason-change! And a change for something better.

I also think it takes conflict to admit that some people (family and friends) would rather see you stay in the muck than move on. I attempt to help students bring this recognition to the foreground and see that there is a price to be paid for such community-switching: the conflict and the pain which has to be expected. In fact, Anzaldua addresses this very issue in her introduction to Making Face, Making Soul. She says, "What does being a thinking subject, an intellectual mean ... for women of color? It means not fulfilling our parents' expectations, it means often going against their expectations by exceeding them.... It means being what Judy Baca terms internal exiles"(xxv).

That's my point. I differ from Anzaldua only in that I believe I have gained more acceptance in my new community than in my old one. There are conferences, journals, and programs in my new community on how to help people like me. And yet last time I visited my brother in the Bronx, I didn't hear of one forum in the bood on how to roll out the red carpet for the eggheads. The idiots on the street corners (and in the families) are still banging the bookworms upside the skull.

I think Lu and her supporters need to get real about the world I'm talking about. Unless someone offers to pay my rent and to put shoes on my little girl, no one is going to convince me that hovering between the two worlds (educated and uneducated) is the place for me. 
One final note: Though I might "quarrel” back, I believe Lu's analysis of conflict in Basic Writing is not only an important one, it is something I wish I had written. This article made me realize that it is important for educators (like $\mathrm{Lu}$ ) to assemble the many voices addressing issues critical to Basic Writers; together I believe we can speak to those who still think that teaching Basic Writing is essentially a matter of skills and drills.

BARBARA GLEASON is Director of the English Composition program at City College. She is Co-Director, with Mary Soliday, of a FIPSE-funded pilot project, The City College Writing Program: An Enrichment Approach to Language and Literacy.

In "Conflict and Struggle in Basic Writing," Min-Zhan Lu builds on themes that appear in her earlier essays. The theme of examining internal language conflicts motivates Lu's autobiographical account of her own language use ("From Silence to Words: Writing as Struggle") and lays a foundation for her argument that deepening a sense of internal language conflicts can enhance a writer's development into a reflective, confident, mature language user. In "Conflict and Struggle" Lu takes this idea a step further by suggesting that these internal conflicts should be foregrounded in the writing class:

We need ... research which explores ways to help students recover the latent conflict and struggle in their lives which the dominant conservative ideology of the 1990s seeks to contain. Most of all, we need to find ways of foregrounding conflict and struggle not only in the generation of meaning or authority, but also in the teaching of conventions of "correctness" in syntax, spelling, and punctuation, traditionally considered the primary focus of Basic Writing instruction. (910)

While I very much appreciate Lu's beautifully written account of her own struggles with Chinese and English in Maoist China, I am less convinced by the directions in which Lu has moved since that earlier essay. I would suggest that a poststructuralist critique, by its very nature, cannot do justice to Basic Writing pedagogy, program development, and research, and that this is especially true in the case of a 1990s critique of a 1970s movement. Secondarily, I suspect that a foregrounding of students' internal conflicts may well serve the teacherresearcher's interests better than it serves the students' needs.

Poststructuralist theories of language share an orientation that foregrounds sociocultural perspectives on language and interprets all kinds of events as primarily linguistic in nature. A curious feature of poststructuralist theories is the prioritizing of the theoretical perspective over the object under analysis. In this system of thought, any particular object (a text, an event, a cultural artifact) is not considered to have its own integrity, its own nature dictating how it is best known. Thus, there is a certain logic to turning a poststructuralist gaze on 1970s Basic Writing literature and practices, even when the prioritized themes of these 
theories-mind, language, culture-do not adequately reveal the fullness and the complexity of the Basic Writing movement or even the ideas and experiences of one Basic Writing teacher.

In the case of Mina Shaughnessy, a critique of her linguistic premises quite simply fails to capture important sociological, educational, and personal dimensions of her work. Take, for instance, Shaughnessy's sophistication and success as a writing program director in a politically complex, male-dominated academic setting. In Lu's analysis, Shaughnessy's formalist approach to language denied her and her students an understanding of the politics of students' linguistic situations. I would argue that a formalist approach to language does not of necessity invoke "innocence" (with an implied naïveté) about the linguistic choices that students might make. Additionally, there is some ambiguity in this use of the term political. Are the languages themselves (as if willed) competing for powerful positions in a given context? Or are the students making choices determined by their political beliefs or by their particular situations?

Lu further asserts that Basic Writing teachers tend to shy away from conflict and struggle: "Open admissions at CUNY was itself an attempt to deal with immediate, intense, sometimes violent social, political, and racial confrontations. Such a context seemed to provide a logic for shifting students' attention away from conflict and struggle and towards calm" (907). I suggest that a close reading of the events of 1969 and 1970 will reveal that Open Admissions was more than an immediate attempt to deal with confrontation; a good deal of discussion about Open Admissions occurred well before the three-week student strike of 1969, and motivations, at least for some, included concern for social inequities and the sort of democratic education that City College has long espoused. If Shaughnessy and her colleagues had a "distrust of conflict and struggle," City College in the early 1970s was not the place for them to be. Moreover, they were mired in practical necessities for which no one was then prepared. If anything underlay their work as teachers, it was this, rather than a formalist theory of language.

As for her linguistic premises, Shaughnessy was working within the dominant paradigm of her day, a time when transformational generative grammar was as intellectually forceful as poststructuralist theory is today (or at least has been in the very recent past). Studies on syntactic maturity flourished, sentence-combining pedagogy promised significant gains for student writers' development, and concerns with readability further turned attention to form. E. D. Hirsch's research on readability and writing was, after all, well supported by research grants (from NEH and from the University of Virginia) between 1971 and the 1977 publication of his Philosopby of Composition. To say that Shaughnessy's pedagogy and research were based on the premise that form is separate from meaning is to say that Shaughnessy was influenced by some of the most commonly accepted premises and theories of her time. Furthermore, given the rapid changes in 
composition since the 1970s, it is a bit misleading to quote Shaughnessy in the present tense, even though this is a commonly accepted academic convention. Shaughnessy thought and wrote fifteen to twenty years ago. It is equally misleading to equate Shaughnessy's epistemological and linguistic premises with those of contemporary Basic Writing teachers who may work from similar ideas. To base one's work on the premise that linguistic form is separate from meaning today may well signify a conservative, perhaps even an uninformed approach; but such cannot be said to be the case in the early to mid 1970s, before Shirley Brice Heath and many others had published research on the ethnographic contexts for literacy, and before literary theories of interpretation became so influential in composition scholarship. It is not even clear to me that most contemporary Basic Writing teachers "continue to emphasize skills," as Lu asserts (889). The prevalence of skills instruction is difficult to determine, since those who do emphasize skills are much less likely to publish than those with more progressive ideas. My own communication with Basic Writing program directors and teachers reveals, at least to some degree, a tendency to look at the remedial class as an opportunity for more instruction on invention, revision, and peer response, rather than for a different kind of instruction, such as skills and drills or direct grammar instruction.

A second difficulty is Lu's suggestion that students' own internal conflicts be foregrounded in the writing class. My primary concern is that this practice may well feed into a current tendency to politicize classroom instruction, an approach that can be as problematic as ignoring the political dimensions of our pedagogies altogether (Lu's "politics of linguistic innocence"). As Maxine Hairston has recently pointed out, students can be just as silenced by a teacher's overt political agenda as by a traditional authoritarian model of instruction. In response to the often stated argument that teachers have political agendas anyway so they might just as well reveal these agendas openly and promote free dialogue, Hairston replies that this is naïve and self-serving. While Hairston's discussion clearly invites further debate, her argument reminds us to reflect seriously on the potential consequences of teachers' espousing their own political views in the classroom.

In the end, I would like to know more about the proposed pedagogy that Lu has in mind. How would students be encouraged to "recover the latent conflict and struggle in their lives ... not only in the generation of meaning or authority, but also in the teaching of [linguistic] conventions" (911)? And, even more importantly, does Lu's own pedagogy inject her political beliefs into the classroom? What if the students hold dear "the dominant conservative ideology of the 1990s"? And what if their religions are somehow entwined with a conservative ideology? Is it really the role of the writing instructor to challenge the students' ideologies when they do not conform to the teacher's? Lu reports that at an 
earlier age she was herself "silenced" on the very issues that she promotes for writing pedagogy ("From Silence to Words"). How would her proposed pedagogy deal with others who are also silenced, unable or unwilling to confront internal language conflicts in the writing classroom? And, finally, are language conflicts to be privileged above all of the other sorts of internal and external conflicts that beset students who are often working, providing for families, and surviving in difficult home situations and neighborhoods? Perhaps these are issues that Lu has come to terms with for herself, but nowhere do I find them addressed in her discussion of pedagogy in the Basic Writing class.

THOMAS J. FARRELL of the University of Minnesota at Duluth is the co-editor of Media, Consciousness, and Culture: Explorations of Walter Ong's Thought (Sage, 1991), of Faith and Contexts, two volumes of essays by Walter 7. Ong (Scholars Press, 1992), and of Communication and Lonergan: Common Ground for Forging the New Age (Sheed \& Ward, 1993).

Neither Min-Zhan Lu nor Paul Hunter has presented an entirely satisfying account of the Basic Writing movement in general or the particular manifestations of that movement at the City College of the City University of New York. Some points in their accounts of the past deserve further comment, as do Lu's prescriptions for Basic Writing today.

Hunter's analysis of the articles in one issue of the fournal of Basic Writing is undoubtedly clever. Since he apparently finds the categories "conservative" and "radical" to be meaningful, he sets out to defend the late Mina P. Shaughnessy (1924-1978) from the possibility of being perceived as a conservative and suggests that she could be seen as a radical. But why? I do not recall Mina Shaughnessy ever saying or writing anything that remotely resembled the kind of stuff Richard Ohmann wrote in English in America, which was published long enough before her death that she conceivably could have read it or at least heard of it. She was not a radical.

Hunter's article turns into an exercise in good guys vs. bad guys. E. D. Hirsch, Jr., is the "bad guy," Shaughnessy the "good guy." I know from conversation with her that Mina Shaughnessy herself did not see Hirsch as a "bad guy," which is probably why he was invited to contribute a piece to the conference in her memory at City College. She did not live long enough to see Hirsch's Cultural Literacy, and she may not have even had the opportunity to read his Philosophy of Composition before she died. Even if she had lived to this day, though, it is hard to imagine that she would ever be among those today who are demonizing Hirsch-as Hunter does. 
Mina Shaughnessy was a magnanimous person. She had a great spirit. I last spoke with her when she was in the hospital with the cancer that she later died from. Sarah D'Eloia Fortune, who herself died of cancer in 1990, was already there visiting her when I arrived. Mina told me in the course of our conversation that Don Hirsch had visited her earlier. Sarah and I left together; I remarked that I was struck by Mina's keen interest in knowing what I had been doing since I had left City College. Sarah said that she had been visiting her regularly and that she had seen her express that kind of keen interest in what others were doing on numerous occasions. She clearly admired Mina's ability to take such a keen interest in others when she herself was in the hospital. I did too. It is a rare ability.

Sarah felt that her life had been enriched by Mina's interest in her. While I certainly did not have as much contact with Mina as Sarah did, I do feel that my contact with her during the year I taught at City College (which Mina arranged for me to do, I should add), and subsequently, enriched my life, too. I suspect that many others would say the same thing. For example, I recall that Mina once told me with obvious fervor her impressions of Susan Miller, whose review of Hirsch's Pbilosophy of Composition Hunter quotes. I imagine that Susan Miller's life was enriched by her contact with Mina, as most likely was Hirsch's life.

Mina Shaughnessy's magnanimity enabled her to have an almost charismatic effect on people. When I remember my conversations with her, I can think of only one apt way to characterize them: I felt blessed by her. I say this because neither Hunter nor Lu seems to be aware of the impact she had on people by virtue of her personality, which may have been a bigger factor in her influence on the Basic Writing movement than anything she ever wrote. Shaughnessy's influence on the Basic Writing movement cannot be assessed properly by just reading her publications without considering the impact of her personality.

Similarly, whatever influence my articles may have had cannot be properly assessed by just reading them without considering the larger context of scholarly discourse at the time. As I explicitly acknowledged in my articles, I was drawing on the thought of Walter J. Ong, Eric A. Havelock, Lev S. Vygotsky, and others. The three articles of mine that Lu cites were published in 1974, 1977, and 1978. Ong served as president of the Modern Language Association in 1978, and in that year he published "Literacy and Orality in Our Times," which generously called attention to my $1977 C E$ article cited by Lu. While "The Writer's Audience Is Always a Fiction" is the most frequently cited essay by Ong, "Literacy and Orality in Our Times" is the most frequently reprinted; it has been reprinted ten times. Since $\mathrm{Lu}$ is aware of the academic prestige of Geoffrey Wagner, Louis Heller, and Lionel Trilling (893), I think she would have to consider that at least part of whatever influence my articles may have had came from the prestige of Ong. In light of the kinds of statements being made in the 1970s by then-prestigious 
figures like Wagner, Heller, and Trilling, it surely enhanced the academic credibility of the Basic Writing movement to have the president of the MLA in 1978 call attention to an article about Basic Writing.

Lu's article continues a critique of Shaughnessy's work that she has published elsewhere. While she seems gracious in characterizing Shaughnessy, Bruffee, and Farrell as "pioneers," Lu's prescriptions for Basic Writing today hardly seem worth pursuing. In place of Lu's suggested prescriptions, let me describe some units I used many times in teaching Basic Writing, which are amenable for use in regular composition courses as well.

I often had the students select a public issue about which there was strong two-sided debate. Since many of them lived in neighborhoods where they were terrorized by people who owned and used guns, gun control was a popular topic for them to investigate. I required them to find two articles in favor of gun control and two against. Naturally we had to rely on the librarians to help instruct them about how to use indexes to look up material about their selected issues. Then they had to look over the various items they were able to find before they selected the four articles they would use. Next, they had to write an accurate summary of each of the four articles in their own words, quoting only sparingly. I then presented them with the standard form for an oration in the classical tradition of rhetoric and explained how it worked. Their assignment was to take a position on the issue they had researched and to include a refutation of the adversarial position before they concluded their presentation. I got wonderful results. So my advice to Basic Writing teachers is to have the students read articles arguing for and against some proposed course of action; and have them summarize arguments both for and against; and then have them write a position paper that includes a refutation of the adversarial position.

In addition, I would encourage Basic Writing teachers today to teach Chinua Achebe's novels Things Fall Apart and No Longer at Ease. Since the latter is a sequel to the former, they are best taught in tandem. (I have described how I taught those novels in "Developing Literacy: Walter J. Ong and Basic Writing"; other helpful sources are Bernth Lindfors's collection on teaching Things Fall Apart, Emmanuel Obiechina's "Narrative Proverbs in the African Novel," and Walter Ong's "Orality-Literacy Studies and the Unity of the Human Race.") I once had a white police officer as a student who in terms of explicit statements sounded like an unabashed racist. But after he read Tbings Fall Apart, he wrote that he could imagine himself sitting down under a palm tree drinking palm wine and talking things over with Okonkwo, the main character in the novel. To paraphrase Hopkins, glory be to God for a novel that can evoke responses like that.

While No Longer at Ease has not yet enjoyed the immense popularity of Tbings Fall Apart, it is a worthy sequel. Walter Ong offers these helpful observations: 
In his sensitive novel No Longer at Ease, concerned with the acculturation of his native Nigeria, Chinua Achebe cogently portrays (pp. 126-27) the awesome impression which knowledge of writing has made on a thoughtful elderly man, who is fascinated by its order and stability and rather given to explaining this order and stability to illiterate kinsmen. He urges them to meditate on Pilate's words (which he quotes in oral fashion, that is thematically, not verbatim, suppressing Pilate's "I"): "What is written is written." The same man is even more impressed by print. He never destroys a piece of printed paper, but in boxes and the corner of his room saves every bit of it he can find. Order so assured as that of printed words deserves to be preserved, whatever the words say. It appears reasonable that such experience of this spectacularly ordered environment for thought, free from interference, simply there, unattended and unsupervised by any discernible person, would open to the overstrained psyche the new possibility of withdrawal into a world away from the tribe, a private world of delusional systemization-an escape not into violence or tribal magic, but into the interior of one's own consciousness, rendered schizoid but once and for all consistent with itself. (Presence 136-37)

Apart from the incident involving that elderly man, the novel presents ample material for discussing the impact of higher education on a person who comes from a largely oral tradition, which is similar to the situation of many Basic Writing students. Since both novels abound in proverbs, they can be used to discuss oral tradition in different cultures.

PAUL HUNTER teaches writing courses at North Lake College in Irving, Texas. He bas published in College English, the Journal of Basic Writing, Teaching English in the Two-Year College, and otber journals.

$\boldsymbol{A}$ few months ago, after years of reading Kenneth Burke, I decided to take Burke's advice and read John Dewey. As I waded more deeply into Dewey's work and commentary on it, I noticed the following: when I got past the numerous festscbriften and accounts of the man's generous and gentle "personality," the man struck me as a genuine American radical. And I have continued to read with excitement and enthusiasm. I am puzzled, however, as to how it came to pass that I could ever have considered this man and his work to be "safe," and therefore dull. What subtle messages had I been receiving that led me to that erroneous conclusion? I'd consciously passed over his books for a couple of decades, rarely taking one down from its shelf. What a shame for me if I had left the conversation without ever having met Dewey!

That recent experience has helped me to understand why I needed to write about Mina Shaughnessy. I am a Basic Writing teacher who has now spent two decades in Open Admissions colleges. I remain excited about that work, which I see as parallel in several ways to the work of the first generation of Sophists: teaching rhetoric to people newly enfranchised by democracy at a time when the 
primary medium of thought and communication is changing. I hope that others who undertake that work in a radical spirit will read Shaughnessy's work and find within it a radical mentor; such was my experience in the mid-1970s.

As a follower of Shaughnessy, I have to take some responsibility for the way that Shaughnessy's work is received by people in my profession. I was very troubled when, in the mid-1980s, I was annotating the fournal of Basic Writing for a CCCC bibliography and could no longer ignore the Shaughnessy memorial issue. Though nothing in it struck me as anything other than generous, the radical spirit that a decade earlier had leaped off the pages of Errors and Expectations late at night in an office shared by ten teaching assistants in a firetrap temporary building was not present in those articles. To the contrary, I found in those articles a Shaughnessy quite different from the one I had encountered when I was ready for the teacher to appear. I found a Shaughnessy who was "safe."

Attending CCCCs for a number of years, I found that Shaughnessy's work had passed out of the conversation, that she no longer was allowed to speak in the present tense. What a shame, I thought, if my younger colleagues do not encounter the radical spirit of Mina Shaughnessy that I had encountered. Maybe I was just not accepting middle age gracefully, but I decided to respond to what I saw and heard and felt in my profession. The result is the article I published in December of 1992. And I would not change a thing about it.

Especially not the word "radical." Professor Farrell, I think, is playing a game with that noun to suggest that it covers only a certain type of ideology, like the one represented by the writer whom he cites. Please. People who call themselves radicals are not united by ideology-some are dogmatic Marxists, some Jamesian pragmatists. Frank Lentricchia opens Criticism and Social Change with a discussion of what it means to be a radical (1-8). I'll quote a paragraph from Burke that Lentricchia paraphrases:

The followers of John Dewey's educational theories make a distinction between "education as a function of society" and "society as a function of education." To restate our own position with reference to this terminology, we should say that a society is normal when education can be a function of society. That is, the principles and directives of the society are operating smoothly, and education prepares the minds of the young by equipping them to maintain these same principles and directives. We are "alienated," "dispossessed" insofar as this order must be reversed, as the followers of Dewey would reverse them. To say that "society" should be a function of "education" is to say, in effect, that the principles and directives of the prevailing society are radically askew (that the society has been despoiled of its reasonableness) and that education must serve to remake it accordingly. (331-32)

That is Lentricchia's view, and my view, of what constitutes a "conservative" and what constitutes a "radical"; "liberals, in this scheme, are nervous conservatives" (1). 
I consider it a privilege to be part of a resurgence of interest in Shaughnessy's work, and I don't think it important that those of us writing about her agree among ourselves on much of anything. Those who feel qualified to write about her "personality" ought to do so; I have no personal warrants of that sort. Those who want to write about Shaughnessy in the past tense may do so; the "site" of Errors and Expectations may indeed be "vanishing." I won't defend myself against the charge of "demonizing" Professor Hirsch; having reviewed what I have written, I think my response to Hirsch stands well enough on its own.

All I'd like to do is to point out that a radical spirit has been covered up and lies smothered beneath mounds of praise, not mounds of criticism.

MIN-ZHAN LU is an assistant professor of English at Drake University. She teaches composition, literary and cultural criticism, and autobiography.

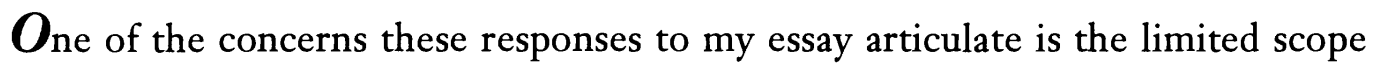
of my account of the conditions surrounding Mina Shaugnessy's work. Let me therefore begin by talking about the book my colleague Bruce Horner and I are completing (tentatively titled Representing the "Other": Basic Writers and the Teaching of Basic Writing), of which my essay "Conflict and Struggle" is a part. In this book, we address at length the respondents' concern that we situate the work of "the three pioneers" in the complex and specific historical contexts of the "birth" of Basic Writing at CUNY, an issue I was not able to develop fully within the space limitations of a journal essay. The book manuscript devotes one chapter to mapping, in Michel Foucault's term, the "adjacency" between the writings of the "pioneers" and those of scholars such as Basil Bernstein, William Labov, Walter Ong, and Lev Vygotsky. Another chapter reads the discursive practices of the "pioneers" in relation to the multiple roles they served as writing teachers, researchers, and writing program directors as well as in relation to a whole range of discursive positions made possible by diverse discourses within and outside English studies, including those of the mass media, CUNY public relations and in-house administrative literature, alumni and faculty writings, the discourse of the student New Left, and CUNY student writings.

I believe the major objections raised in the responses to my essay result from a confusion about the kind of history of Basic Writing we are writing, one informed by Michel Foucault's notion of discourse. Our history, following Fredric Jameson's injunction, "historicizes" genealogically (139). Specifically, our history studies the discursive and institutional formations of Basic Writing since its "birth" and its social effects in the present, focusing particularly on the interrelationships among language, power, knowledge, agency, and resistance. This kind of history has two aspects: a "critical aspect" analyzing instances of discursive control, and a "genealogical aspect concerning the effective formation 
of discourse" (Foucault 233). The history we are writing explores questions like the following: How does the dominant discourse on those called Basic Writerswhat we refer to as the "new" discourse of Basic Writing-work? Where is it to be found? How does it get produced and regulated? What are its social effects? In raising these genealogical questions and questions about the functions of discourse, we hope to distinguish our account from and thus intervene in the kinds of approaches to "history" concerned with the causal influences among events or with the evolution of ideas (from "false" or "erroneous" to "true") whose "unity" and "origin" supposedly reside in the "intention" and "integrity" of the individual "author," approaches which seem to govern many of the objections raised in the responses. This difference is best illustrated by the respondents' reading of my critique of the discourse of Errors and Expectations as an attack on Mina Shaughnessy's intentions, personality, or career achievements, as evidenced by their repeated references to these.

Given the design of our project, it is not surprising that a section of it, namely my essay "Conflict and Struggle," would provoke reaction from those identified with the positions made possible by the discourse we critique. Professor Laurence's response illustrates in most explicit terms the power of that discourse to regulate the position of those who use it. Although she argues for the irrelevance of the "pedagogy of struggle" to City College in the name of "difference" and historical and social "specificity," she builds her argument on forms of dualistic and essentialist thinking I critique in "Conflict and Struggle." For example, she maintains that "difference' is structured into the institution [City College] in its 80 percent minority enrollment." Based on this factor and the "stormy beginnings" of the Open Admissions movement, Laurence concludes that "to have employed a vocabulary or metaphor of 'conflict' and 'struggle' (then or now) rather than the language of understanding, caring, exchange, and reciprocity would have been counterproductive, irresponsible, and explosive." Laurence labels any use of such words as "conflict" and "struggle" as "polarizing" language. But her argument itself polarizes by situating the vocabulary of "conflict" and "struggle" as distinct from and opposed to the vocabulary of "understanding, caring, exchange, and reciprocity." In her discourse, one is either "caring" or provokes "conflict." Thus she is unable to recognize the cultural dialogue and negotiation built into the kind of "conflict and struggle" I am advocating. This prompts me to risk repeating myself: part of the reason I promote the image of the new mestiza and the notion of education as a process of repositioning is precisely because these concepts offer a way of thinking beyond the trap of polarization which seems to have dominated much of the earlier debate over "the students' right to their own language" and current debate over so-called Political Correctness (illustrated, for example, by James Traub's polarization of politics and education in "P. C. vs. English: Back to Basic"). 
Most "borderlands" writings I admire discuss in explicit terms the need to "act on" rather than "react to" all forms of dualism in society. As far as I am concerned, the purpose of calling students' attention to cultural conflicts is to help them to locate forms of polarization and "othering," to examine where these dualisms come from and what their social consequences might be, and to explore new positions which struggle against-i.e., break-rather than perpetuate the boundaries sustaining polarizations which separate and hierarchize different cultures. The goal of engaging students in "a process of repositioning" is to help them imagine alternatives to dominant forms of not only stances but also "counterstances," which are, as Anzaldua points out, limited by and dependent on what they are reacting against, locked into a duel of self/otber and the "common denominator of violence" (Borderlands/La Frontera 78). "Counterstances" lead to reacting and impede the forming of a new mestiza consciousness, which involves massive uprooting of dualistic thinking in the individual and collective consciousness. Anyone interested in forming such a new mestiza consciousness would therefore realize that it demands a "willingness to share," to make oneself "vulnerable to foreign ways of seeing and thinking," and to respect not only one's own but also the other's right to equality (Borderlands/La Frontera 82). It requires the courage to undergo radical change in one's consciousness and society. Therefore, contrary to Professor Laurence's prediction, we might well combat polarization through a pedagogy that poses conflict and struggle as an integral part of rather than as counter to caring, reciprocity, exchange, and negotiation.

I don't think it is a coincidence that the conjunctions and adverbs most frequently employed by writers from the borderlands are "both," "simultaneously," "not only ... but also," and "as well as." Using the image of a "critical organic catalyst," Cornel West urges minority intellectuals to "simultaneously position themselves within (or alongside) the mainstream (staying attuned to the best of what the mainstream has to offer-its paradigms, viewpoints, and methods) while clearly aligned with groups who vow to keep alive other traditions of critique and resistance" (33). He further reminds us that "openness to othersincluding the mainstream-does not entail wholesale cooptation, and group autonomy is not group insularity." Likewise, bell hooks urges us to recognize margins as "botb sites of repression and sites of resistance," as a place not only of "deprivation" and "wound" but also of "creativity and power" (342-43). However, hooks also rightly cautions us that we tend to be "more often silenced" when engaged in this alternative discourse (342). Such is the case, I believe, because it challenges the either/or approach which, I argue in "Conflict and Struggle," has dominated much of the discourse on Basic Writing when it comes to discussing the kinds of positions Basic Writers ought to take towards conflicting cultures.

I see Professor Laurence's dismissal of the pedagogy of struggle as an illustration of the formative power of the either/or format. It seems to have inscribed 
not only her resistance to discourses attempting to think beyond the either/or format but also her distrust in her students' potential to be interested in, and capacity to move beyond, that kind of "polarized pro/con format," a distrust John Trimbur sees in Maxine Hairston's portrayal of "high risk" classrooms (Trimbur 249). Trimbur traces the power of such a format to television programs such as Firing Line and Crossfire and the kind of forensic rhetoric students learn in high school debates. I would add that this format is also likely to be disseminated in the kind of classroom Professor Farrell has promoted since the 1970s and details once again in his response. And it is most likely to recur in classrooms where teachers view students as standing either defiantly or helplessly outside, or comfortably inside, a particular culture. I don't think it is coincidental that the only words Laurence cites from her students depict the "student" as "the grass that suffers"-helplessly caught beneath the feet of fighting elephants. It appears that Professor Laurence has difficulty imagining that students might well be interested in and capable of rejecting polarized stances. Two opposed images dominate the representations of City students she provides: on the one hand, she depicts the "rage and frustration of minority students" staging an "educational drama" in 1969 and the "conflicts among African-Americans, Koreans, and Jews" (interestingly enough, an image that absolves the "majority" of the city from any role in these "conflicts"); on the other hand, she also depicts students eagerly "seeking an education that would enable them to join the mainstream." What she does not imagine are students who might actively seek to become the kind of "organic catalyst" West promotes. Instead, in her vision, they must either stand defiantly/helplessly outside the academy or move unequivocally into the center of it.

I agree with Professor Laurence's argument that it is dangerous to treat Basic Writers in homogeneous terms, but I disagree with her use of statistical data to make the argument that "difference' is structured into" the classrooms at City College but will be lesser in "predominantly white, and perhaps 'elite,' institutions." Laurence thus implies that the "cultural questions and conflicts" surfacing in "her" classrooms are caused solely by the physical presence of the 80 percent "minority" students. For her, the intensity of "difference" seems to correspond directly to the specific number and variety of students with non-white skin colors, non-Anglo-Saxon backgrounds, and non-English native tongues. This view of the constitution of conflicting "cultural identities" is reductive; it rests on the assumption that one's cultural identifications are strictly genetically inherited rather than socially and discursively constructed, often unconsciously reproduced but also capable of being consciously chosen, resisted, or transformed.

The inability to move beyond the either/or format also surfaces in Professor Rondinone's response. Here again, as in his other writings, Professor Rondinone paints the "differences" between the "worlds of the uneducated and the educated" in black and white: one world consists of "idiots" with "values not worth clinging 
to" and the other offers nothing but "conferences, journals, and programs" to help people like himself. In his writing, these two worlds remain static, absolutely self-consistent, totally separate from one another, and unequivocally hierarchized. I want to emphasize that I do not disagree with Professor Rondinone's view that indiscriminate and sentimental valorization of one's home or "minority" community is debilitating for anyone interested in advancing the interests of that community. Anzaldua (as Rondinone points out), West, and hooks have all discussed the need to acknowledge and combat all forms of violence and oppression in "minority" as well as "majority" cultures. In advocating a mestiza "tolerance for contradiction and ambivalence," I am by no means asking Professor Rondinone to "hover" in "suspension" between two discrete worlds. Neither am I asking him to identify uncritically with and participate in any of the self-destruction, crime, racism, and sexism he repeatedly claims to have witnessed in the "hoods." Rather, I am suggesting that he might want to consider the possibility of fighting and changing both worlds and their existing interrelationships. I repeat that I criticize his stance not because he has the courage to call attention to values and practices in minority communities which run counter to the interests of those groups, but rather because he does so without also raising a series of other questions. For example, what might be the values and practices of the "uneducated" ("idiots" to Rondinone) that are "worth clinging to" by someone concerned to advance the interests of those caught on the "street corners" of the "hoods"? Why? What might be the values and practices of the "educated" which are "not worth clinging to" for that person? Why? To what extent might the oppression and violence among the "uneducated" be related to some of the values and practices of the "educated"? What might be the social sources and consequences of the "worst" of both worlds? What might be the ways of combating them and changing both worlds? Those questions are silenced in Professor Rondinone's discourse, a discourse that interpellates those who employ it to become passive "survivors," rather than active reformers, of the "realities" in which they find themselves.

In her response, Professor Gleason voices the concern that "a foregrounding of students' internal conflicts may well serve the teacher-researcher's interests better than it serves the students' needs." Since she does not discuss the particular kinds of "needs" she has in mind nor why and how these "needs" might be incompatible with the teacher's interest in foregrounding conflict, I can only surmise that this concern stems mostly from her belief that foregrounding conflict may "feed into a current tendency to politicize classroom instruction," making students "silenced by [the] teacher's overt political agenda." Although I agree with Professor Gleason that we should "reflect seriously on the potential consequences of teachers' espousing their own political views in the classroom," I am troubled by Gleason's implicit equation of reflection on the politics of writing/teaching with the domination of the teacher's political views. I'd argue 
that such consequences are unlikely if the reflection is carefully accompanied by the notion of education as a process of repositioning.

Professor Gleason's equation, I believe, is a line of thinking more related to the particular representation of "the students' needs" and capacity surfacing in Professor Gleason's response than to the kind of pedagogy I promote. As Trimbur points out in his response to Hairston's "low-risk" classroom promoted in "Diversity, Ideology, and Teaching" (to which Professor Gleason refers), the line of thinking indicates a view of students "as potential dupes 'ripe for intellectual intimidation," a view which "can only have the effect of reproducing students as spectators, perpetually on the verge of being overwhelmed by the experts who have the credentials to speak" (Trimbur 249). Professor Gleason asserts that foregrounding students' internal conflicts may not serve "the students' needs" but fails to explain how she knows what those "needs" are. Thus, her statement implies that whatever "needs" she has in mind are self-evident "facts" or "truths" inherent in students rather than a discursive and political construct shaped by a particular form of discourse: knowledge arrived at by taking a particular theoretical perspective (such as a "[non-]poststructuralist" perspective) towards a particular "object" of study (in this case, students identified by that discourse as Basic Writers). By the logic of this implication, only the teacher/researcher who acknowledges her theoretical perspective runs the risk of "prioritizing of the theoretical perspective over the object [the student] under analysis," not the one who ("untheoretically"?) just knows "the students' needs."

The risk of reproducing students as spectators is likely to be greater in classrooms which present the teacher's knowledge of "the students' needs" as self-evident and directly corresponding to predetermined and unchangeable "facts" about who the students are, what the society is like, and what action is in the best interests of such students. In contrast, the theoretical perspective sustaining the kind of classroom I promote understands the formative power and the subjugating effect of discourse. In such a classroom, the teacher's knowledge, whether it be of the students' needs or of cultural/intellectual resources, is presented to students as a discursive construct motivated by specific social interests and capable of producing specific social effects. Such an understanding would not permit either teacher or students to forget the political agenda espoused by such discursive constructs or the pressures these constructs exert on speakers to perceive themselves and to behave as active agents capable of coping with conflict and bringing about change. This classroom would also pose the question of how the speaker ought to reposition herself in response to such pressures, as well as to pressures exerted by forms of knowledge which define students as passive receptacles of existing truth interested only in "surviving," or accommodating themselves to, existing conditions. A teacher seriously putting such a theoretical perspective into practice would have to take on the burden of allowing and 
helping each student to think through the material consequences that her decision on how to reposition herself would have on her thoughts and action, as well as on the shape of her life and her relationship to others and the world. And that teacher would have to recognize the student's potential interest in and ability to choose positions which go against rather than alongside the position endorsed by the teacher, including positions like those Gleason enumerates. And the teacher would encourage each student to enact this process of repositioning in the context of the particular conditions of her life, conditions which are in turn defined in terms of the whole range of cultural sites often silenced by "academic discourse" (race, ethnicity, gender, sex, economic class, education, religion, region, recreation, work, etc.) and defined also in terms of the life she has lived in the past, is living in the present, and envisions for the future. Although I promote the use of images of the mestiza and of education as a process of repositioning for all students, these images would not and cannot "homogenize" students in the way Professor Laurence accuses me of doing. Rather, these images, when accompanied by such a definition of "the conditions of life," would push those who employ them to attend to the specificity of the individual situation and the heterogeneity among students labeled "Basic Writers."

I agree with Professor Gleason that, given the power relationships built into the institutional roles of the teacher in present-day North America, it would be "naïve and self-serving" to assume that the "dialogue" and "resistance" promoted in the kind of classroom I depict can be absolutely free of social and discursive constraints. But I do not think it naïve and self-serving to assume that students are nevertheless capable of and interested in negotiating with power in infinite ways within the space delimited by such constraints, especially if and when the teacher trusts and urges them to do so (see Garth Boomer et al., Negotiating the Curriculum). Furthermore, I think it naïve and self-serving to assume that the classroom is any less "politicized" or less in danger of espousing the teacher's agenda when the teacher treats her own representations of the "needs" and abilities of the students as self-evident "facts" devoid of political interests. In foregrounding the political dimension of discursive practices, the teacher takes on the burden of putting all ideas and actions, her own as well as those of each student, under rigorous scrutiny. Thus, the teacher cannot shirk her responsibility of having spoken for the "student"- of having taken a subject position towards that "object of study"-no matter how much it might be that teacher's intention to fully capture the "object's own integrity, its own nature indicating how it is best known," as Gleason puts it. And she would have to invite the student to look into the unexamined logic of the teacher's discourse and search for alternative forms of defining and approaching that "object." Conversely, a classroom treating the teacher's knowledge of the student as self-evidently "factual," supposedly inherent in the "object's own integrity" and "its own nature dictating how it is best known," 
risks leading students to passively accept the teacher's knowledge. Thus, students are more likely to be "silenced by the teacher's [unannounced] political agenda" if they are not asked or allowed to reflect on the role both students and teachers have played in espousing it.

However, I cannot agree more with Professor Gleason on the need to address the series of questions she raises at the end of her response. My own attempts to contribute to addressing such questions are represented in other of my publications and conference presentations (e.g., "The Teaching of 'Usage' in the Contact Zone"). Among other works, besides those already cited, I would refer readers sharing Gleason's interest in those questions to works by David Bartholomae and Anthony Petrosky, Tom Fox, Carolyn Hill, Bruce Horner, Glynda Hull and Mike Rose, Elaine Lees, and Mike Rose. It is true, of course, that any discussion of how to practice such a pedagogy in the form of a step-by-step teaching manual would contradict the injunction of this pedagogy to attend fully to the specific and dynamic interaction inherent in all discursive practice. Nevertheless, detailed descriptions of particular interactions in our classrooms can help us analyze the principles sustaining our activities and speculate on the strengths and limitations of these principles in a variety of teacher/student relationships. This symposium, in giving me the opportunity to hear and respond to oppositional views, has further illuminated for me the urgent need for this type of research by those of us interested in promoting the images of the "mestiza" and "education as a process of repositioning." I appreciate the opportunity to exchange ideas about this agenda.

\section{WORKS CITED}

Anzaldua, Gloria. Borderlands/La Frontera. San Francisco: aunt lute, 1987.

- Making Face, Making Soul. San Francisco: aunt lute, 1990.

Bartholomae, David, and Anthony Petrosky. Facts, Artifacts, and Counterfacts. Upper Montclair, NJ: Boynton/Cook, 1986.

Boomer, Garth, et al. Negotiating the Curriculum. London: Falmer, 1992.

Burke, Kenneth. Attitudes Toward History. Los Altos: Hermes, 1959.

D'Eloia, Sarah, ed. “Toward a Literate Democracy.” Fournal of Basic Writing 3.1

(1980). Special issue published as a memorial to Mina Shaughnessy.

Farrell, Thomas J. "Developing Literacy: Walter J. Ong and Basic Writing." Fournal of Basic Writing 2.1 (Fall/Winter 1978): 30-51.

Ferguson, Russell, ed. Out There. Cambridge: MIT P, 1990.

Foucault, Michel. The Archaeology of Knowledge and the Discourse on Language.

Trans. A. M. Sheridan Smith. New York: Pantheon, 1972. 
Fox, Tom. "Basic Writing as Cultural Conflict." Fournal of Education 172.1 (1990): 65-83.

Graff, Gerald. "Teach the Conflicts." Soutb Atlantic Quarterly 89 (1990): 51-67. Hairston, Maxine. "Diversity, Ideology, and Teaching." College Composition and Communication 43 (May 1992): 179-93.

Hill, Carolyn. Writing from the Margins: Power and Pedagogy for Teachers of Composition. New York: Oxford UP, 1990.

Hirsch, E. D., Jr. Culteral Literacy: What Every American Needs to Know. Boston: Houghton Mifflin, 1987.

- The Pbilosopby of Composition. Chicago: U of Chicago P, 1977.

hooks, bell. "marginality as site of resistance." Ferguson 341-43.

Horner, Bruce. "Rethinking the 'Sociality' of Error: Teaching Editing as Negotiation." Rbetoric Review 11 (1992): 172-99

Hull, Glynda, and Mike Rose. "'This Wooden Shack Place': The Logic of an Unconventional Reading." College Composition and Communication 41(1990): 287-98.

Jameson, Fredric. The Political Unconscious. Ithaca; Cornell UP, 1981.

Laurence, Patricia. The Vanishing Site of Mina Shaughnessy's Errors and Expectations." Fournal of Basic Writing (Fall 1993).

Lees, Elaine. "The Exceptable Way of the Society: Stanley Fish's Theory of Reading and the Task of the Teacher of Editing." Reclaiming Pedagogy: The Rhetoric of the Classroom. Ed. Patricia Donahue and Ellen Quandahl. Carbondale: Southern Illinois UP, 1989. 144-63.

Lentricchia, Frank. Criticism and Social Change. Chicago: Chicago UP, 1983.

Lindfors, Bernth, ed. Approacbes to Teaching Acbebe's Things Fall Apart. New York: Modern Language Association, 1991.

Lu, Min-Zhan. "From Silence to Words: Writing as Struggle." College English 49 (April 1987): 433-48.

—. "Redefining the Legacy of Mina Shaughnessy: A Critique of the Politics of Linguistic Innocence." Journal of Basic Writing 10 (Spring 1991): 26-40.

—. "The Teaching of 'Usage' in the Contact Zone." Conference on College Composition and Communication. San Diego, 1993.

—. "Writing as Repositioning." Fournal of Education 172.1 (1990): 18-21.

Obiechina, Emmanuel. "Narrative Proverbs in the African Novel." Oral Tradition 7 (1992): 197-230.

Ohmann, Richard. English in America. New York: Oxford UP, 1976. 
Ong, Walter. "Literacy and Orality in Our Times." ADE Bulletin 58 (September 1978): 1-7. Rpt. (among other collections) in A Sourcebook for Basic Writing Teachers. Ed. Theresa Enos. New York: Random, 1987.

—. "Orality-Literacy Studies and the Unity of the Human Race." Oral Tradition 2 (1987): 371-82.

- The Presence of the Word. 1967. Minneapolis: U of Minnesota P, 1991.

—. "The Writer's Audience Is Always a Fiction." PMLA 90 (1975): 9-22.

Rose, Mike. Lives on the Boundary. New York: Penguin, 1989.

Shaughnessy, Mina. Errors and Expectations: A Guide for the Teacher of Basic Writing. New York: Oxford UP, 1977.

Traub, James. "P.C. vs. English: Back to Basic." The New Republic 8 February 1993: 18-19.

Trimbur, John. "Counterstatement." College Composition and Communication 44 (May 1993): 248-49.

West, Cornel. "The New Cultural Politics of Difference." Ferguson 19-36. 